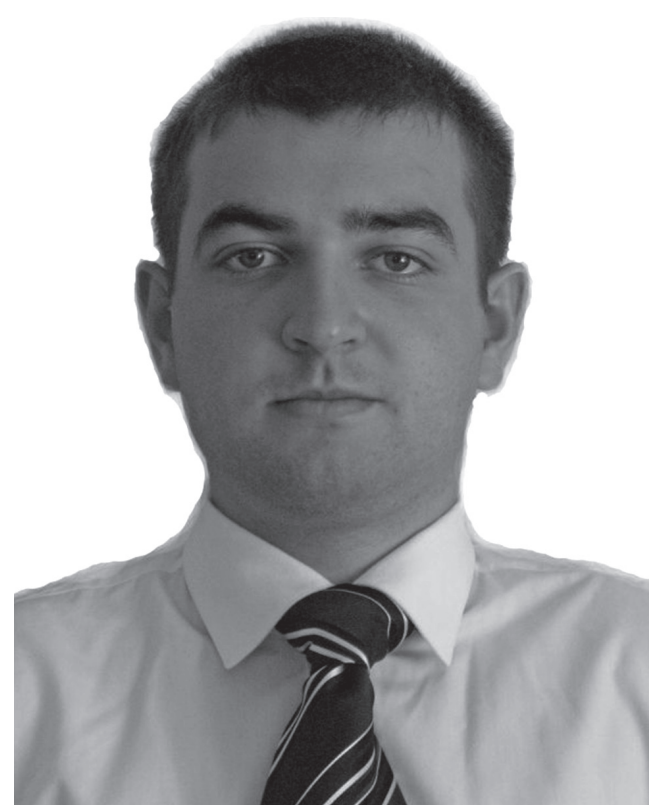

DOI https://doi.org/10.32689/2617-2224-

2019-16-1-74-83

UDC: 338.43.02:636 (477) “71”

Лаврук Олександр Валерійович, докторант кафедри публічного адмініструування, Міжрегіональна Академія управління персоналом, 03039, м. Киї, вул. Фрометівська, 2, тел.: (067) 46597 25,e-mail: arhangelprime@gmail.com

ORCID: 0000-0002-7932-0036

Лаврук Александр Валериевич, докторант кафедрь публичного администрирования, Межрегиональная Академия управления персоналом, 03039, 2. Киев, вул.Фрометовская, 2, тел.: (067) 46597 25, e-mail: arhangelprime@gmail. com

ORCID: 0000-0002-7932-0036

Lavruk Alexander Valerievich,

doctoral student of the Department of Public Administration, Interregional Academy of Personnel Management, 03039, Kyiv, Str.Frometivska, 2, tel.: (067) 46597 25, e-mail: arhangelprime@gmail.com

ORCID: 0000-0002-7932-0036

\title{
ДЕРЖАВНА ПОЛІТИКА У РОЗВИТКУ ТВАРИННИЦТВА УКРАЇНИ
}

Анотація. Акцентується увага на актуальності питання прискореного рівня політичного розвитку держави, оновлення пріоритетів та цінностей політичної культури населення України. Зазвичай такі інноваційні процеси потребують формування нових завдань перед державною політикою в аграрному виробництві. Дослідження грунтуються на використанні інформаційних ресурсів, узагальненні наукових розробок вітчизняних і закордонних вчених, особистих спостереженнях. Зазначено необхідність подолання кризових явищ у тваринництві як однієї з провідних галузей економічного зростання виробництва, які потребують відповідного впливу держави шляхом формування системи державного управління та реалізації ефективної державної політики. Визначено сутність державної політики, що становить сукупність форм, методів, принципів та інструментів, за допомогою яких держава впливає на діяльність тваринницьких підприємств та на функціонування ринку тваринницької продукції.

Доведено, що одним із напрямів державної політики є розширення можливостей тваринництва для використання сучасних технологій з метою 
виробництва нових видів високоякісної тваринницької продукції. Встановлено, що від існуючих проблем у тваринництві залежить не лише соціальноекономічний розвиток держави, а й рівень її продовольчої безпеки. А тому державна політика за допомогою ухвалених державно-політичних рішень повинна регулювати постійно виникаючі людські потреби в продуктах тваринного походження з можливістю держави і суспільства їх задовольняти. Відповідно вказується на необхідність спрямування заходів державної політики на покращення державної підтримки, яка передбачає здійснення, за рахунок фінансування з державного бюджету, інноваційного оновлення i регулювання виробничої діяльності тваринницьких підприємств. Запропоновано Міністерству аграрної політики України розробити заходи науково обгрунтованої та ефективної державної політики, яка б забезпечила розвиток конкурентоспроможного тваринництва на внутрішньому та зовнішньому ринках.

Ключові слова: держава, державна політика, тваринництво, державне управління, тваринницька продукція, населення, продовольча безпека.

\section{ГОСУДАРСТВЕННАЯ ПОЛИТИКА В РАЗВИТИИ ЖИВОТНОВОДСТВА УКРАИНЫ}

Аннотация. Акцентируется внимание на актуальность вопроса ускоренного уровня политического развития государства, обновления приоритетов и ценностей политической культуры населения Украины. Обычно такие инновационные процессы требуют формирования новых задач перед государственной политикой в аграрном производстве. Исследования базируются на использовании информационных ресурсов, обобщении научных разработок отечественных и зарубежных ученых, личных наблюдениях. Указывается на необходимость преодоления кризисных явлений в животноводстве, одной из ведущих отраслей экономического роста производства, которые требуют соответствующего влияния государства путем формирования системы государственного управления и реализации эффективной государственной политики. Определена сущность государственной политики, представляющая собой совокупность форм, методов, принципов и инструментов, при помощи которых государство обеспечивает влияние на деятельность животноводческих предприятий и на функционирование рынка животноводческой продукции.

Доказано, что одним из направлений государственной политики является расширение возможностей животноводства для использования современных технологий с целью производства новых видов высококачественной животноводческой продукции. Установлено, что от существующих проблем животноводства зависит не только социально-экономическое развитие государства, но и уровень его продовольственной безопасности. Поэтому государственная политика, при помощи принятых государственно-политических решений, должна урегулировать постоянно возникающие человеческие потребности в продуктах животного происхождения с возможностью государства и общества их удовлетворять. Соответственно указывается на 
необходимость направления мероприятий государственной политики на улучшение государственной поддержки, которая предусматривает осуществление, за счет финансирования из государственного бюджета, инновационного обновления и регулирования производственной деятельности животноводческих предприятий. Предложено Министерству аграрной политики Украины разработать меры научно обоснованной и эффективной государственной политики, которая бы обеспечила развитие конкурентоспособного животноводства на внутреннем и внешнем рынках.

Ключевые слова: государство, государственная политика, животноводство, государственное управление, животноводческая продукция, население, продовольственная безопасность.

\section{STATE POLICY IN THE DEVELOPMENT OF ANIMAL HUSBANDRY IN UKRAINE}

Abstract. Attention is focused on the relevance of the issue of accelerated political level of development of the state, updating the priorities and values of the political culture of the population of Ukraine. Typically, such innovation processes require the formation of new tasks of state policy in agricultural production. Research is based on the use of information resources, generalization of scientific developments of domestic and foreign scientists, personal observations. The purpose of the article is to determine the essence and theoretical approaches to the formation and implementation of state policy in the development of the livestock industry. The necessity of overcoming the crisis phenomena in animal husbandry, one of the leading branches of economic growth of production, requiring the appropriate influence of the state through the formation of public administration and the implementation of effective public policy. The essence of the state policy is defined, which is a set of forms, methods, principles and tools by which the state provides influence on the activities of livestock enterprises and the functioning of the market of livestock products.

It is proved that one of the directions of the state policy is the expansion of opportunities for livestock use of modern technologies for the production of new types of high-quality livestock products. It is established that not only the socioeconomic development of the state, but also the level of its food security depends on the existing problems in animal husbandry. Therefore, the state policy, with the help of the adopted state and political decisions, should regulate the constantly emerging human needs in animal products with the possibility of the state and society to meet them. Accordingly, the need to direct public policy measures to improve state support, which provides for the implementation, through funding from the state budget, innovative renovation and regulation of production activities of livestock enterprises. It is proposed to the Ministry of agrarian policy of Ukraine to develop measures of scientifically sound and effective state policy, which would ensure the development of competitive livestock in the domestic and foreign markets.

Keywords: country, public policy, animal husbandry, public administration, animal products, population, food security. 
Постановка проблеми. Сучасний кризовий стан сільського господарства України потребує втручання держави з метою розробки заходів державної політики (формуються і реалізуються у складних внутрішніх та зовнішніх економічних і соціально-політичних умовах) та їх цільового спрямування на подолання складних і руйнівних процесів у виробничо-господарській діяльності, яка забезпечує збільшення обсягів сільськогосподарської продукції. Відповідно, розвиток тваринництва в країні характеризується щорічним скороченням розмірів виробництва і поголів'я сільськогосподарських тварин, плачевним фінансово-економічним становищем тваринницьких підприємств, зниженням ix інвестиційної привабливості, постійним загостренням конкурентної боротьби, порушенням виробничих відносин між виробниками, переробниками тваринницької продукції та торгівельними структурами. Безперечно, держава зовсім мало допомоги надає такому напряму аграрної діяльності, через що галузь тваринництва й опинилася у такому плачевному стані.

У більшості випадків нестача бюджетних коштів спонукає спрямовувати фінансові ресурси на подальший розвиток таких стратегічних галузей, як свинарство, птахівництво, які прискореними темпами забезпечують ріст обсягів тваринницької продукції і максимальний прибуток. Водночас розвиток м'ясо-молочного скотарства, вівчарства, кролівництва, поступово занепадає, тоді як без цих, як і багатьох інших галузей, важко забезпечити позитивні зміни у рівні життя населення та задоволенні його продовольчих потреб. Усе це потребує втручання держави в існуючу ситуацію з метою моніторингу і пошуку ефективних управлінських заходів для покращення розвитку виробничих, інтеграційних, інноваційних процесів та економічних взаємовідносин між тваринницькими підприємствами. Загалом, лише відповідальність органів влади і ефективна державна політика спроможні забезпечити високий суспільний розвиток, посилення продовольчої безпеки, економічної та соціальної стабільності в країні.

Аналіз останніх досліджень i публікацій. Проблему державної політики та проведення аналізу застосування іiі методів та інструментів вивчали такі зарубіжні вчені: Д. Андерсон, Т. Брус, М. Браун, Д. Веймер, Е. Водунг, Т. Дай, В. Данн та ін.

Теоретико-методологічному аналізу, стратегії державної політики, механізмам іiі впровадження та прийняття управлінських рішень присвятили свої наукові праці такі вітчизняні вчені: В. Бакуменко, О. Валевський, 3. Варналій, В. Воротін, В. Гошовська, О. Кілієвич, М. Латинін, В. Мамонова, П. Мироненко, В. Романов, В. Тертичка та ін.

Проте, досить багато науковотеоретичних питань щодо визначення сутності, особливостей, цілей, регуляторів виконання стратегій, програм розвитку і механізмів впровадження дієвої державної політики та прийняття управлінських рішень щодо подальшого розвитку тваринництва до нині є недостатньо дослідженими. 
Мета статті полягає у визначенні сутності та теоретичних підходів до формування і реалізації державної політики у розвитку галузі тваринництва.

\section{Виклад основного матеріалу.} Нині основною проблемою тваринницьких суб'єктів господарювання є відсутність зацікавленості держави до нарощування кількості поголів'я сільськогосподарських тварин (за 2000-2016 рр. поголів'я великої рогатої худоби в усіх категоріях господарств зменшилося на 60,9\%, свиней - на $12,8 \%$, овець і кіз - на 29,9 \%) та мотивації підприємницьких структур до збільшення обсягів виробництва тваринницької продукції. У цій ситуації доцільно сформувати ефективні варіанти альтернативних параметрів державної політики в інтерпретації цілеспрямованих державних політико-адміністративних заходів, управлінських інструментів (нормативно-правові підстави державно-управлінських дій) і ресурсів (адміністративні, матеріальні, фінансові, інформаційні, людські та політичні можливості) для своєчасного прийняття державних рішень щодо подальшого розвитку тваринництва.

Звичайно, нині забезпечити швидке відновлення досягнутих рубежів у розвитку тваринництва практично неможливо, особливо у визначеній послідовності розроблених державою аграрних програм (Державна підтримка галузі тваринництва та Підтримка утримання молодняка BPX), постанов Кабінету Міністрів (Про затвердження порядку використання коштів, передбачених у державному бюджеті для підтримки галузі тваринництва), Законів України (Про молоко та молочні продукти, Про племінну справу у тваринництві, Про ветеринарну медицину) та інших нормативно-правових актів 3 питань тваринництва, в яких не враховуються нестабільні політичні та складні і непередбачувані ринкові ситуації. Зазначене потребуе здійснення переходу на широке використання нових форм (гнучке та оптимальне поєднання механізмів державного і ринкового регулювання) впливу державних органів на виробничі і технологічні процеси у галузі тваринництва, що уможливить забезпечення його ефективного функціонування та створення конкурентних переваг на світових ринках.

У трансформаційний період, коли відбуваються великі глобальні зміни, державна політика спрямовується на ефективне розв'язання виробничих і соціальних проблем, знаходячись у середовищі складних політичних процесів. При цьому дієва роль держави спрямовується на створення сприятливих умов господарювання, а тому має відповідати трьом основним принципам: ефективність, стабільність, справедливість [1]. У цих умовах надання державою виробникам тваринницької продукції фінансової допомоги сприятиме переведенню тваринництва на інноваційний шлях розвитку та промислову основу організації переробки і збуту тваринницької продукції [2].

Забезпеченню здійснення такого роду процесів передуватиме урахування основних особливостей формування і реалізації державної 
політики: процес ухвалення державних рішень проводиться за участю різних сторін (виборці, виборні посадові особи, державні службовці, суди, групи за сформованими власними інтересами, органи державної влади і місцевого самоврядування) та управлінського апарату (у складі якого знаходиться політичний та адміністративний).

У цьому контексті державна політика має задовольняти такі вимоги:

- своєчасно реагувати на зміни, які відбуваються в суспільстві, державі, регіоні, а також у галузі тваринництва;

- приймати до уваги i розглядати перелік суспільних і виробничих проблем та шляхи їх вирішення;

- комплексно підходити до формування державно-політичних piшень, розробки відповідного інструментарію та механізму їх реалізації;

- за будь-яких ситуацій бути результативною та мати довіру суспільства і населення.

Слід зазначити, що дослідження державної політики дає можливість показати наявність множинних зв’язків між різними індивідами, групами і організаціями. В окремих випадках державна політика поширюється не на все суспільство, а лише на регулювання процесів у конкретних сферах діяльності або ж передбачає вплив на певну суспільну групу. Так, зазначимо, що державна політика являє собою діяльність органів державної влади, що спрямовується на вирішення сукупності взаємозалежних суспільних проблем.

Не випадково під державною політикою вчені розуміють “...діяль- ність, націлену на вирішення проблем суспільного розвитку" [3, с. 21]. Такої ж думки дотримуються інші дослідники, які вважають, що державна політика “...включає визначення проблеми, цілей та інструментів розв'язання проблеми” [4, с. 44]. У даному випадку вважається, що державна політика є лише інструментом, засобом для здобуття і утримання влади певними політичними силами, але без чіткого розподілу завдань, повноважень і відповідальності органів державної, виконавчої влади і місцевого самоврядування. Окремі вчені під дефініцією державна політика розуміють “...відносно стабільну, організовану та цілеспрямовану діяльність уряду стосовно певної проблеми або предмета розгляду, яка здійснюється ним безпосередньо або опосередковано через уповноважених агентів і впливає на життя суспільства" [5, с. 12 ].

Державна політика є вкрай потрібною у суспільному житті, оскільки на неї покладаються функції виявлення виробничих i суспільних проблем, які важливо своєчасно проаналізувати, встановити причини виникнення, складність і можливість своєчасного розв'язання. Наразі, у середовищі державної політики має прийматися не тільки низка державно-політичних рішень, спрямованих на розв'язання соціально-економічних проблем, але й розроблятися науково-стратегічні програми та визначатися інструменти їх реалізації у галузі тваринництва. Необхідність реалізації державної політики обумовлюється потребами прискорення розвитку тваринництва на інноваційній платформі. Стверджується, 
що відсутність інновацій у сільському господарстві і розвитку інфраструктури аграрного ринку призводить до відставання України від провідних держав Європи та світу [6, c. 68].

Оскільки державна політика $є$ одним із базових компонентів політико-управлінської діяльності в галузі тваринництва, то вона залишається об'єктом впливу суспільства і бізнесових структур. У більшості випадків вона формується у публічній сфері суспільних інтересів, цілей та завдань, притаманних не тільки сільському господарству, але й галузі тваринництва, а тому дають можливість сформувати модель (визначається ідеологічними і політичними імперативами, що відповідають новим умовам і потребам) іiі подальшого розвитку на основі якої приймаються політичні, правові та управлінські рішення. Більше того, державна політика сприяє формуванню такого ринкового середовища у галузі тваринництва, яке повною мірою відповідає національним інтересам виробників тваринницької продукції.

Натомість, державі дуже важливо гарантувати забезпечення попиту населення на м'ясо-молочну продукцію з метою стабілізації ринкової кон'юнктури. Інакше “...держава не одержить необхідного обсягу важливих продуктів споживання власного виробництва, що в результаті порушить вимоги національної безпеки продовольчого забезпечення, підвищить ризикованість, пов'язану 3 нестачею продовольчих ресурсів" [7, с. 26]. Назрілі проблеми покладаються на Міністерство аграрної політики і продовольства в частині розроблення різного роду заходів із забезпечення подальшого розвитку тваринництва та підвищенню його конкурентоспроможності на внутрішньому і зовнішньому ринках.

Досить тривалий період державна політика базувалася на застосуванні командно-адміністративних і бюрократичних методів управління виробництвом сільськогосподарської продукції, серед якої вагоме місце посідала тваринницька. Зараз основне завдання державної політики полягає у тому, щоб забезпечити непряму, гнучку систему (притаманну ринковим формам господарювання) втручання у виробничу діяльність та повну фінансову підтримку з метою підвищення інвестиційної привабливості і ефективного розвитку галузі тваринництва. Вкрай важливим аспектом є те, що держава повинна регулювати економічні процеси, забезпечувати реалізацію соціальноекономічних і правових функцій, а сформована державна політика сприяти формуванню відносин 3 виробниками тваринницької продукції на принципах партнерства, взаєморозуміння та дотримання ділових стосунків відповідно до економічних інтересів цієї сфери діяльності.

Прийняття до уваги зазначених напрямів державної політики у розвитку тваринництва дасть можливість створити об'єктивні умови для зростання доходів населення i формування належного рівня життя, що позитивно вплине на процеси інвестування коштів у формування якісних характеристик працівників 
тваринництва та максимальне задоволення їхніх продовольчих потреб. Надалі держава має навчити тваринників ефективно господарювати у складних ринкових умовах з метою прибуткового виробництва продукціï тваринництва. Окрім цього держава зобов'язана з турботою ставитися до працівників тваринництва, створивши при цьому спеціальний фонд соціальних гарантій на випадок подальшого вимушеного скорочення робочих місць в основних підгалузях тваринництва.

Нині спостерігається активний розвиток інститутів громадянського суспільства, які у більшості випадків впливають на законодавчі процеси інститутів державної влади за рахунок активної участі громадськості у формуванні та реалізації державної політики [8]. Відтак, активізується розвиток публічної політики, основним завданням якої $€$ формування механізму виявлення i забезпечення суспільних інтересів. Вона пов'язується 3 втіленням владних повноважень з часу формування різних проблем політики та сприяє прийняттю владних політико-управлінських рішень, для яких вибирається необхідний інструментарій та механізм їх реалізації при здійсненні різних видів діяльності для досягнення суспільних цілей. Доступ до таких рішень можуть мати господарюючі суб'єкти, що зацікавлені у розв'язанні суспільно значущих проблем [9]. Відповідно публічність політики знаходить своє місце там, де вона спрямовується на досягнення суспільних цілей та забезпечення суспільних інтересів [10, c. 193].
Особливо важливу роль слід надати державній регіональній політиці, яка спроможна забезпечити:

- державну підтримку та створення інституціональних умов для розвитку тваринництва i гарантування продовольчої безпеки у кожному регіоні;

- ухвалення державно-політичних рішень з підвищення конкурентоспроможності регіонів за рахунок забезпечення їх високопродуктивним генетичним потенціалом сільськогосподарських тварин та висококваліфікованими людськими ресурсами;

- покращення та посилення співробітництва регіонів у правовому, законодавчому і партнерському полі взаємовідносин та механізм їх реалізації;

- чіткий законодавчий розподіл повноважень і відповідальності між загальнодержавним, регіональним i місцевим рівнями управління.

Не варто применшувати важливість науково обгрунтованої i ефективної державної політики сільського розвитку (відповідає європейським цінностям та європейській практиці), оскільки малий i середній виробник продукції став i. пріоритетом. Наукові підходи і моделі такої політики до цих пір для більшості членів суспільства характеризуються новацією і тому потребують публічного обгрунтування проблем розвитку основних галузей, що забезпечують продовольчу проблему країни. Наразі державна політика використовує систему типових методів законодавчого, виконавчого і контрольного характеру, часто використовуваних правочинними дер- 
жавними органами для забезпечення результативності соціально-економічних відносин і виробничих процесів у галузі тваринництва.

Висновки і перспективи подальших досліджень. Проведені дослідження показали, що державна політика є одним з важливих елементів і критеріїв життєдіяльності суспільства (спрямовується на покращення соціальної стабільності та рівня життя громадян), окремих виробничих сфер і галузей діяльності, зокрема тваринницької (забезпечує населення продовольством та гарантує продовольчу безпеку країни). А тому усі аспекти (моделі, інститути, інструменти, програми, процеси формування і реалізації, оцінка і регулювання ) державної політики широко і всесторонньо досліджуються та у різних варіантах подання трактуються зарубіжними і вітчизняними науковцями. Однак, у наукових дослідженнях державної політики не варто надавати пріоритети лише методам і важелям iï управлінського впливу на соціально-економічні і політичні процеси, але й акцентувати увагу на планування, організацію i моніторинг функцій кожного її елементу.

У перспективі не применшується важливість дослідження державної політики, оскільки вона обумовлюється характерними особливостями запитів суспільства та сучасних політичних процесів прийняття владно-політичних рішень, що формуються у середовищі політичної системи. У контексті зазначеного передбачається більш поглиблене дослідження проблем розроблення і застосування державної політики не тільки у різ- них сферах суспільного життя, але й у сільському господарстві та його основних галузях, які формують продовольчу безпеку країни.

\section{СПИСОК ВИКОРИСТАНИХ ДЖЕРЕЛ}

1. Самуельсон П. Экономика: в 2 т.: пер. с англ. / П. Самуельсон. М.: НПО Алгон, 1992. Т. 1.510 c.

2. Коляденко С. В. Організаційно-економічні засади тваринницької продукції в Україні/ Сталий розвиток економіки. 2011. № 6. С. 6-10.

3. Валевський О. Л. Державна політика в Україні: методологія аналізу, стратегія, механізми впровадження: [монографія]. - К.: НІСД, 2001. 242 с.

4. Бажал Ю., Кілієвич О., Мертенс О. та ін. Економічний розвиток і державна політика: [навч. посіб.]. К.: Вид-во УАДУ, 2001. 480 с.

5. Романов В. Є., Рудік О. М., Брус Т. М. Державна політика: аналіз та механізми ії впровадження. - Дніпро: ДРІДУ НАДУ, 2003. 72 с.

6. Тульчинська С. О. Дослідження методичних підходів оцінки розвитку соціальної інфраструктури в регіонах / С. О. Тульчинська, С. О. Кириченко // Економічний вісник НТУУ “КПІ”. Вип. 14. К.: Політехніка, 2017. С. 67-74.

7. Місюк М. В. Ринок продукції скотарства: монографія. К.: ННЦ "IАЕ", $2012.330 \mathrm{c}$.

8. Постанова Кабінету Міністрів України "Про забезпечення участі громадськості у формуванні та реалізації державної політики" [Електронний ресурс]. Режим доступу: http:zakon3.rada.gov.ua/laws/ show/996-2010-\%D0\%BF

9. Ситник С. В. Політичні аспекти організації нормотворчості в Украіні // Відкриті очі. 2014 [Електронний ресурс]. Режим досту- 
пу: http://www.vidkryti-ochi.org. ua/2014/11/blog-post.html

10. Телешун C., Ситник C., Рейтерович I. Публічна чи державна політика вітчизняна дилема вибору. Вісник Національної академіі державного управління при Президентові України. 2012. Вип. 4. С. 185-196 [Електронний ресурс]. Режим доступу: http://nbuv.gov.ua/UJRN/ Vnadu_2012_4_25

\section{REFERENCES}

1. Samuelson P. (1992), Ekonomika [Economy], NPO Alhon, Moscow, Russia.

2. Kolyadenko S. V. (2011), "Organizational and economic basis of animal products in Ukraine", Stalyi rozvytok ekonomiky, vol. 6, pp. 6-10.

3. Valersky O. L. (2001), Derzhavna polityka v Ukraini: metodolohiia analizu, stratehiia, mekhanizmy vprovadzhennia [State policy in Ukraine: methodology of analysis, strategy, mechanisms of implementation], NISD, Kyiv, Ukraine.

4. Bazhal J. Kilievich O. and Mertens $O$. (2001), Ekonomichnyi rozvytok i derzhavna polityka [Economic development and public policy], Vydavnytstvo UADU, Kyiv, Ukraine.

5. Romanov V. Ye. Rudik, O. M. and Brus T. M. (2003), Derzhavna polityka: analiz ta mekhanizmy yii vprovadzhennia [Public policy: analysis and mechanisms of its implementation], DRIDU NADU, Dnipro, Ukraine.

6. Tulchynska S. O. and Kirichenko S. O. (2017), "Research of methodological approaches to assessing the development of social infrastructure in the regions”, Ekonomichnyi visnyk NTUU “KPI”, vol. 14, pp. 67-74.

7. Misyuk M. V. (2012), Rynok produktsii skotarstva [The market of livestock products], NNTs “IAE”, Kyiv, Ukraine.

8. Cabinet of Ministers of Ukraine (2015), "Resolution of the Cabinet of Ministers of Ukraine "Ensuring public participation in the formation and implementation of state policy", available at: http://zakon.rada.gov.ua (Accessed 06 October 2018).

9. Open eyes (2014), Sitnik, S.V. "Political aspects of norm-setting organization in Ukraine", available at: http:// www.vidkryti-ochi.org.ua/2014/11/ blog-post.html (Accessed 06 October 2018)

10. Teleshun S. Sitnik, S. and Reiterovich I. (2012), "Public or public policy-domestic dilemma of choice", Bulletin of The national Academy of public administration under the President of Ukraine, Vol. 4, available at: http:// nbuv.gov.ua/UJRN/Vnadu 2012_4_25 (Accessed 06 October 2018). 